\title{
Habitat suitability models and carrying capacity estimations for rock ptarmigans in a protected area of the Italian Alps
}

\author{
Luca Nelli
}

\begin{abstract}
Rock ptarmigan populations in the Alps are suffering an overall decline, and management actions are needed to ensure their conservation. Yet wildlife management and conservation actions are often the consequences of political decisions taken by subjects that lack the scientific knowledge about the relationships between the environment and species ecology. Habitat suitability models are tools that translate these complex relationships into mathematical models and spatially explicit maps of potential presence and abundance of species that are easier to understand by people not experienced with the study of biological processes. In this study, I modelled the species-habitat relationships at two levels, by estimating the potential distribution and potential density of the species in a protected area of the Western Italian Alps. In particular, I took the results of a previous study carried out in the same area to estimate the probability of male occurrence by comparing the habitat structure in presence plots and random plots, respectively, by logistic regression analyses. Then, I applied the logistic regression equation to the same variables measured in hexagonal cells of a grid superimposed over the entire study area, and I obtained the map of the potential distribution of the species. Finally, I developed multiple regression analyses of male density estimated by distance sampling vs habitat variables, and I applied the results to the areas of potential distribution to forecast the potential density and therefore the carrying capacity of the study area. I obtained a potential distribution of $38.2 \mathrm{~km}^{2}$, with a potential average density of $5.1 \mathrm{males} / \mathrm{km}^{2}$. The latter was positively affected by the percentage cover of grassland and rocky grassland in the plots. The integrated approach that I used by combining models of occurrence and density allowed me to confirm and improve the results of previous works on rock ptarmigan predicted occurrence, to identify areas of conservation importance within the protected area and to give useful tools for spatially explicit management to the Natural Park administrators.
\end{abstract}

Key words: Carrying capacity, Habitat suitability, Lagopus muta helvetica, Italian Alps, Potential distribution, Rock ptarmigan, Species distribution models.

Riassunto - Le popolazioni italiane di pernice bianca alpina presentano uno stato di conservazione sfavorevole e appaiono in declino generalizzato su tutto l'arco alpino. Ciononostante, le azioni di gestione volte ad assicurarne la conservazione sono spesso prese in conseguenza

Department of Earth and Environmental Sciences, University of Pavia, Via Ferrata 9, 27100 Pavia, Italia.

E-mail: luca.nelli@unipv.it

\section{(C) 2015 Luca Nelli}

Received: October 13, 2014

Accepted for publication: November 20, 2014 di decisioni politiche di organi che non sono necessariamente in possesso delle nozioni sulle relazioni esistenti tra habitat ed ecologia della specie. I modelli di idoneità ambientale sono strumenti che traducono queste relazioni complesse in modelli matematici e supporti cartografici, che sono più facili da comprendere anche da chi non ha esperienza dei processi ecologici. In questo lavoro ho modellizzato le relazioni habitat-specie stimando la distribuzione e la densità potenziali dei maschi di pernice bianca in un'area protetta delle Alpi Occidentali. In particolare ho utilizzato i risultati di un precedente studio effettuato nella stessa area, per stimare la probabilità di presenza dei maschi di pernice bianca mediante modelli di regressione logistica. Successivamente ho applicato l'equazione logistica risultante alle stesse variabili misurate in celle esagonali di una griglia sovrapposta all'area di studio, al fine di ottenere una mappa della distribuzione potenziale. Infine ho utilizzato una regressione multipla per descrivere la densità dei maschi, stimata mediante distance sampling, in funzione delle variabili ambientali, e ho applicato i risultati nelle aree di presenza potenziale per stimare la capacità portante dell'area per la specie. Ho ottenuto una distribuzione potenziale di $38,2 \mathrm{~km}^{2}$, con una densità media potenziale di 5,1 maschi $/ \mathrm{km}^{2}$, influenzata positivamente dalla percentuale di praterie e praterie rupicole. L'approccio integrato che ho utilizzato, combinando i due modelli di presenza e densità, mi ha permesso di confermare e affinare i risultati del precedente studio sulla presenza della pernice bianca nell'area protetta, di identificare le aree più importanti per la conservazione e di fornire strumenti per una corretta gestione della specie ai gestori del Parco.

Parole chiave: Alpi italiane, capacità portante, distribuzione potenziale, Lagopus muta helvetica, modelli di distribuzione, pernice bianca.

\section{INTRODUCTION}

Habitat suitability models represent one of the most useful tools in wildlife management. More than just knowledge itself of species biology or of an environmental system, the possibility of passing this knowledge on to the people in charge of management and conservation decisions is the real key to a proper wildlife management (Pitelka \& Pitelka, 1993), particularly when models can be used to provide spatially explicit tools as distribution maps.

To predict the potential distribution and density of a species, resource selection functions can be used to synthesize the process of habitat selection into a mathematical expression (Boyce et al., 2002) that can be easily understood by people not experienced with the study of biological processes. The use of tools such as Geographical Information Systems (GIS) and digital data as land-use maps are often used for this purpose (Brambilla et al., 2009). 
Most of the studies about habitat selection concentrate their efforts in determining the potential distribution of species, modelling the species-environment relationships and estimating the probability of the species presence, or occurrence, as a response to habitat variables (Liu et al., 2005; Allouche et al., 2006; Miller, 2014). In some cases, results of occurrence models are considered as indicators of species abundance. These processes are based on the hypothesis that presence data follow an abundance-related detection probability (Jiménez-Valverde, 2011) and that occurrence models reflect habitat suitability and therefore a higher probability to have high densities of animals (Estrada \& Arroyo, 2012). Yet, extrapolating abundance directly from predicted probability of presence should be avoided because there are many and complex factors that can affect this relationship (Nielsen et al., 2008; Estrada \& Arroyo, 2012). On the contrary, models that put in relationship habitat variables with the abundance of a species can be used as tools to improve the results obtained with occurrence models.

The rock ptarmigan (Lagopus muta) is classified as a species of Least Concern by the Global IUCN Red List Category and Criteria, but at a local level, the subspecies $L$. m. helvetica is suffering an overall decline throughout whole Alpine range and particularly in Italy, where it is listed in the Italian Red List as Vulnerable (Peronace et $a l ., 2012$ ) and has a 'bad' conservation status (Gustin et al., 2009). Italian populations of the species have a discontinuous distribution (De Franceschi, 1992; Spagnesi $\&$ Serra, 2004) and spring densities are often lower than in the rest of the subspecies range (Favaron et al., 2006; Clementi et al., 2008, Zohmann \& Wöss, 2008).
Degradation, fragmentation, and loss of suitable habitat due mostly to anthropogenic and natural processes and other factors such as sport activities, tourism, climate change, poaching, and over-hunting are considered the most important reasons for the decline of this species (Storch, 2000; Zeitler, 2001; Watson \& Moss, 2004; Rotelli, 2006; Storch, 2007).

Identifying suitable breeding areas for a species that is highly susceptible to anthropogenic disturbance such as the rock ptarmigan is required to preserve the most suitable breeding sites from disturbance during critical periods, such as pair formation, egg incubation, and the first weeks of brood rearing.

The aim of the present study was to develop two habitat suitability models for breeding male rock ptarmigans in a protected area of Western Italian Alps by identifying the habitat that affected the probability of both occurrence and density of the species, supply potential distribution and potential density maps, and estimate the carrying capacity of the species in the considered area.

\section{MATERIALS AND METHODS}

\section{Study area}

My study was carried out in Veglia-Devero Natural Park in the western Italian Alps close to the border with Switzerland (Fig. 1). The Park covers $107.9 \mathrm{Km}^{2}$ with a mean altitude of $2274 \mathrm{~m}$ a.s.l (min: 1371, max: $3563)$. The main cover types were bare rocks $(45.7 \%)$, alpine grassland (29.7\%), and larch forest (14.5\%) (for-

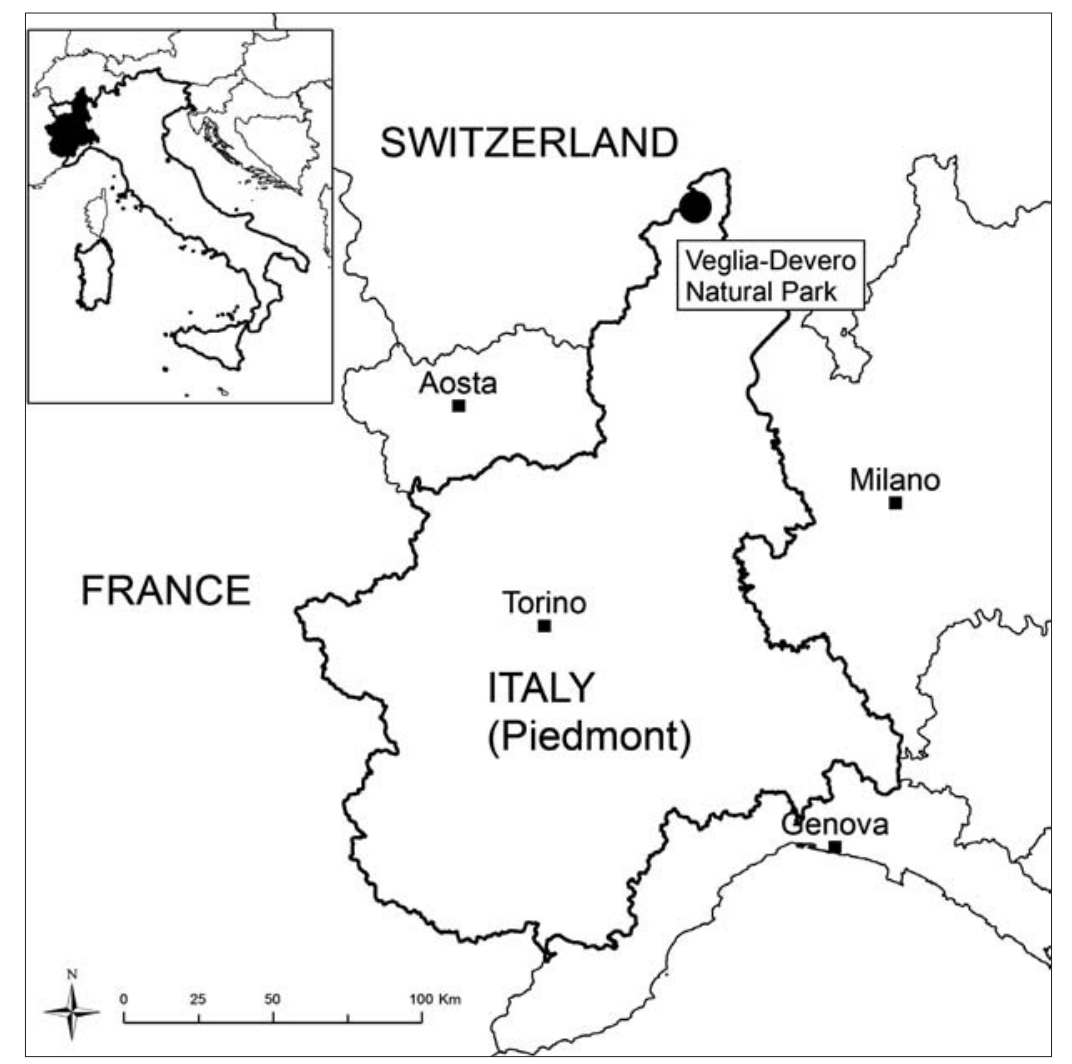

Fig. 1 - Location of Veglia-Devero Natural Park, Italy. 
estry and other land-use categories map of the Piedmont Region, available at http://www.regione.piemonte.it/agri/ area_tecnico_scientifica/suoli/dati.htm). The climate was alpine with an average yearly temperature of $4.6^{\circ} \mathrm{C}(\mathrm{min}$. in January $-4.4^{\circ} \mathrm{C}$, max. in July $12.4^{\circ} \mathrm{C}$ ) and an annual average precipitation of $1467 \mathrm{~mm}$ falling primarily as rain in the summer (meteorological station, data from 1991 to 2012, available at http://www.regione.piemonte.it/ambiente/aria/rilev/ariaday/annali/idrologici).

The sample area $\left(14.5 \mathrm{~km}^{2}\right.$, Fig. 2) was in the northeast part of the Park. Mean altitude was $2387 \mathrm{~m}$ a.s.l. (min: 2009, max: 2694). The main cover types were alpine grasslands $(70.5 \%)$ and bare rocks $(21.2 \%)$.

\section{Data collection}

For the present work, I used the data collected in Nelli et al. (2013). We conducted surveys from 20 May-20 June in 2010 and 2011 using counts of calling cocks. We established 30 random sampling points within the study area using the software QGIS 2.0. We surveyed vocalizing rock ptarmigan males for 60 minutes during the hours of maximal calling activity (0400-0530; Wöss \& Zohmann, 2004; Nopp-Mayr \& Zohmann, 2008) during which we recorded all calling cocks, their exact or approximate location, and the exact time of each call. When we observed calling cocks, we measured the exact distance from the observer to the bird with a laser rangefinder (Leica Rangemaster 900; Leica, Solms, Germany). When we did not see a calling bird, we mapped the approximate position of the calling bird on aerial photographs (1:5.000 scale) based on the likely attenuation and direction of its vocalization. We then measured the distance from observer to the likely position of each cock using the software QGIS. For further details, see Nelli et al. (2013).

\section{Data analyses}

In Nelli et al. (2013) we analyzed habitat selection by breeding rock ptarmigan males by formulating different resource selection functions with a use vs. availability approach. In particular, we used logistic regression analyses (LogRA) to compare the proportions of cover-type categories found within a 37-ha circle, the average core area of breeding rock ptarmigan males on the Alps (Favaron et al., 2006), surrounding each observed bird using three classification maps of differing information and resolution, with those measured in the random circles. We also evaluated physical variables (altitude, slope, and solar radiation) using a 75-m digital terrain model. The best model we obtained that described the presence of male rock ptarmigans was the one including the habitat variables obtained from the forest resources map of the Italian Piedmont Region.

Here, I subdivided the territory of the Park into a hexagonal cell grid of 37 ha each. I chose a hexagonal grid because hexagons were the closest approximation of circles that allowed me to uniformly cover the study area. I measured the cover-type and physical variables in each cell, then I used the results of the best model obtained by

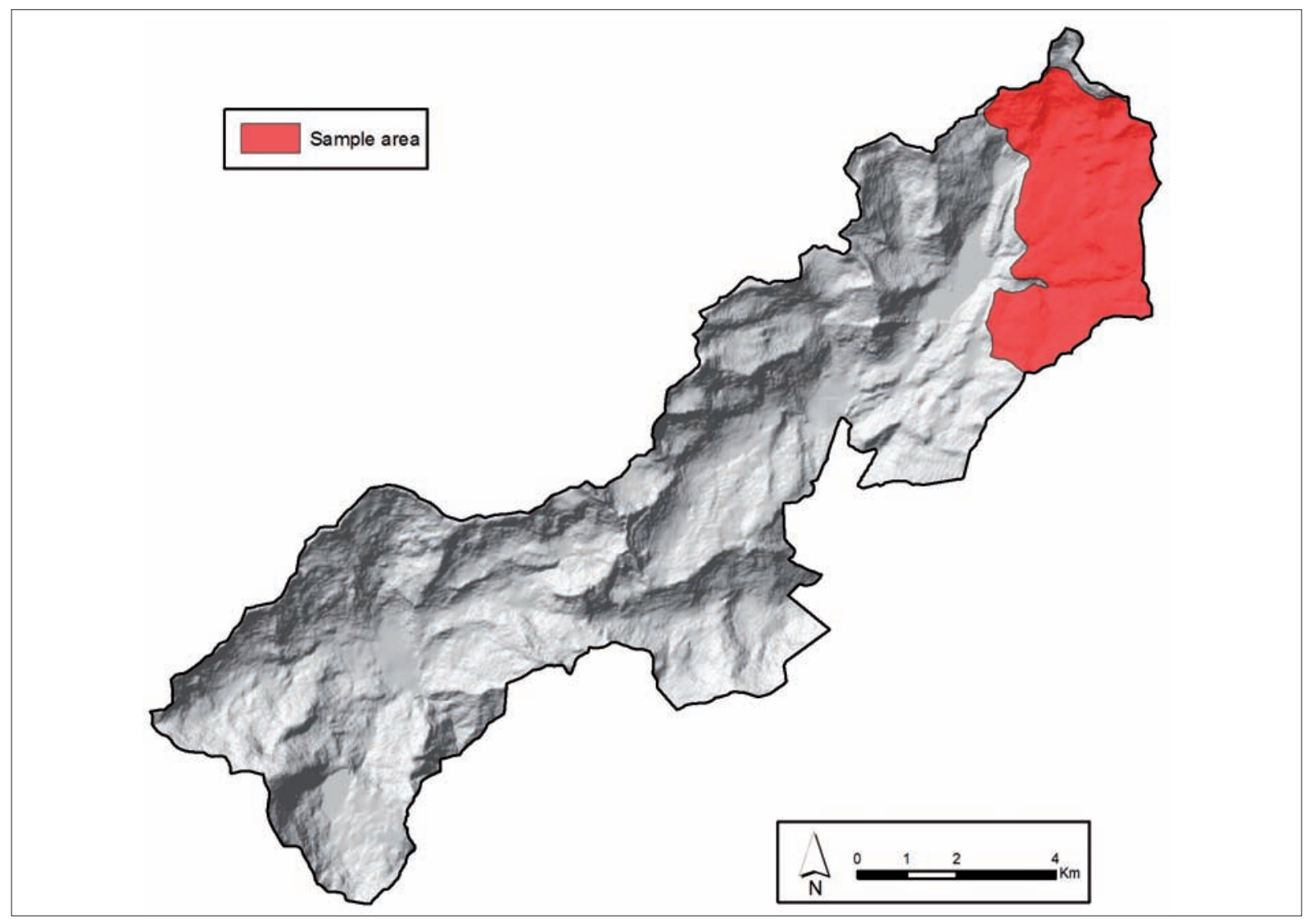

Fig. 2 - Location of the sample area within the Veglia-Devero Natural Park, Italy. 
Nelli et al. (2013) to build a map of the potential distribution of male rock ptarmigans by applying to the area the logistic regression equation:

$$
\text { probability of presence }=e^{z} /\left(1+e^{z}\right)
$$

where $\mathrm{z}=0.006-0.030 \times$ altitude standard deviation + $0.036 \times$ rocky grassland $+0.103 \times$ alpine lakes +0.001 $\times$ altitude.

In this way, I obtained a potential distribution map of the species by considering the cells with a probability of presence higher than 0.5 (Manel et al., 1999a, 1999b; Bailey et al., 2002). The purpose of this method was to develop the model for carrying capacity only in the potential distribution areas.

In Franceschi et al. (2014), we estimated cock density by Distance sampling in the same sample area and with the same data of the present study.

Here I used the results of that work to evaluate the density value for each sample site (observation point) by applying the best detection function we obtained to the encounter rate of each sample. To evaluate the effect of habitat variables on density, I carried out linear models (LM) of cock density vs the habitat variables measured in a 37-ha circle around each observation point. In particular, I used the variables obtained by the forest resources map of the Piedmont Region since it was the map that allowed us to obtain the best results in Nelli et al. (2013); furthermore, using QGIS I evaluated aspect by calculating average northness and eastness in the plots starting from a 25 $\mathrm{m}$ digital terrain model with the formulas (Zar, 1999):

$$
\begin{gathered}
\text { northness }=\cos (\operatorname{asp} * \pi / 180) \\
\text { eastenss }=\sin (\operatorname{asp} * \pi / 180)
\end{gathered}
$$

where asp is the original aspect measured in 360 degrees in the digital terrain model.

In this way, I obtained variables varying from -1 to +1 , where -1 indicates, respectively for northness and eastness, a higher exposure to south and to west and +1 a higher exposure to north and to east.

For the model selection, I followed the information theoretic approach (Akaike, 1973) with multi-model inference. I ranked the models by the corrected value of Akaike's information criterion (AIC) and by relative importance expressed as their Akaike's weights ( $\mathrm{w}_{\mathrm{i}}$; Anderson et al., 2000, 2001). Each models with $\Delta \mathrm{AIC}<2$ was validated by testing for the deviation from normality of the residual distribution by a Shapiro-Wilk normality test and calculating the variance inflation factor (VIF) to detect collinearity among predictors (Zuur et al., 2010). I used the selected models to calculate the average model. Finally, I used the regression coefficients of the average model to forecast the potential density of male rock ptarmigans in each hexagonal cell by applying the regression equation.

\section{RESULTS}

After applying the LogRA equation to the study area, I obtained a potential distribution of $38.2 \mathrm{~km}^{2}$ that corresponds to $35.2 \%$ of the Park territory (Fig. 3).

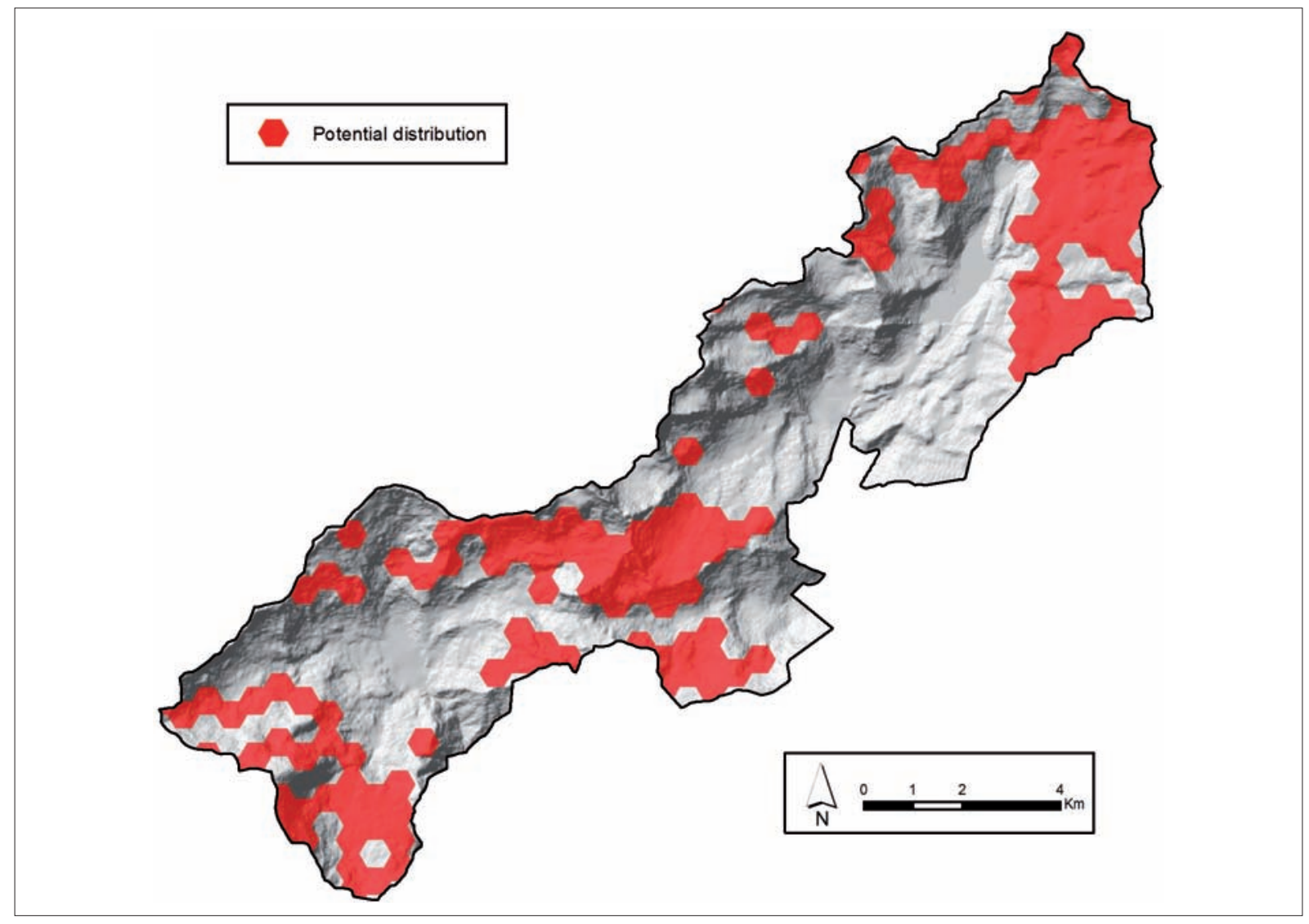

Fig. 3 - Potential distribution of male rock ptarmigans in the Veglia-Devero Natural Park, Italy. 
Tab. 1 - AICc of the multiple regression models of male rock ptarmigan density in the Veglia-Devero Natural Park, Italy. Only models with $\triangle \mathrm{AICc}$ are shown. $\mathrm{AICc}=$ corrected Akaike's information criterion, $\triangle \mathrm{AICc}=$ difference in AICc between a given model and the best model, $w=$ Akaike's weight, $\mathrm{VIF}=$ variance inflation factor.

\begin{tabular}{|l|l|c|c|c|}
\hline Model & Variables (VIF) & $\mathbf{A I C}_{\mathbf{c}}$ & $\mathbf{\Delta A I C}$ & $\mathbf{w}$ \\
\hline 1 & Northness (1.007), grassland (1.126), rocky grassland (1.133) & 89.44 & 0.00 & 0.41 \\
\hline 2 & $\begin{array}{l}\text { Eastness (1.215), northness (1.192), grassland (1.152), rocky grassland } \\
(1.133)\end{array}$ & 89.89 & 0.45 & 0.33 \\
\hline 3 & Grassland (1.126), rocky grassland (1.126) & 90.29 & 0.85 & 0.27 \\
\hline
\end{tabular}

In the sample area, we detected 42 male rock ptarmigans. By distance sampling we estimated a density $( \pm$ SE) of $5.5 \pm 0.99$ males per $\mathrm{km}^{2}$ in 2011 (Franceschi et al., 2014).

With multi-model inference, I selected 3 models that predicted the number of male rock ptarmigans well $(\Delta \mathrm{AIC} \leq 2, \mathrm{Tab} .1)$. The model that explained the variance of the dependent variable best was the one that included northness, grassland percentage, and rocky grassland percentage. The other two models had a good predictive power: one included eastness in addition to the former variables $\left(\triangle \mathrm{AIC}_{\mathrm{c}}=0.45\right)$ and the other contained only grassland and rocky grassland $\left(\triangle \mathrm{AIC}_{\mathrm{c}}=0.58\right)$. The VIF values showed no collinearity among predictors in all three models, and all of them had a normal distribution of residuals (Shapiro-Wilk test; all $\mathrm{P}>0.2$ ).

The most important variables were the percentage of grassland and rocky grassland $(\Sigma \mathrm{W}=1)$, which both had a significant positive effect on male rock ptarmigan density. Northness and eastness had a negative effect, but they were less important, in terms of predictive power, and not significant (Tab. 2).
The carrying capacity of the Park territory, given by the average model applied to all the suitable cells as resulted by the LogRA model, was 174 male rock ptarmigans with a potential average density $\left( \pm\right.$ SE) of $5.1( \pm 0.27)$ males $/ \mathrm{km}^{2}$ and 95\% confidence intervals between 4.5 and 5.6 (Fig. 4).

Tab. 2 - Model averaged coefficient ( $\beta$ ) of habitat variables for the prediction of male rock ptarmigan density in the Veglia-Devero Natural Park, Italy. LCI $=95 \%$ lower confidence interval, $\mathrm{UCI}=$ upper confidence interval, $\Sigma \mathrm{W}$ = sum of Akaike's weights.

\begin{tabular}{|l|r|r|r|r|}
\hline Variable & \multicolumn{1}{|c|}{$\boldsymbol{\beta}$} & \multicolumn{1}{|c|}{ LCI } & UCI & \multicolumn{1}{|c|}{$\Sigma \mathbf{w}$} \\
\hline (Intercept) & $\mathbf{0 . 5 9}$ & $-\mathbf{0 . 4 2}$ & $\mathbf{1 . 6 0}$ & - \\
\hline Grassland & $\mathbf{0 . 0 1}$ & $\mathbf{0 . 0 0}$ & $\mathbf{0 . 0 2}$ & $\mathbf{1 . 0 0}$ \\
\hline Rocky grassland & $\mathbf{0 . 0 3}$ & $\mathbf{0 . 0 1}$ & $\mathbf{0 . 0 5}$ & $\mathbf{1 . 0 0}$ \\
\hline Northness & $-\mathbf{1 . 1 0}$ & $-\mathbf{2 . 2 3}$ & $\mathbf{0 . 0 2}$ & $\mathbf{0 . 7 3}$ \\
\hline Eastness & $-\mathbf{0 . 5 9}$ & $-\mathbf{1 . 3 8}$ & $\mathbf{0 . 1 9}$ & $\mathbf{0 . 3 3}$ \\
\hline
\end{tabular}

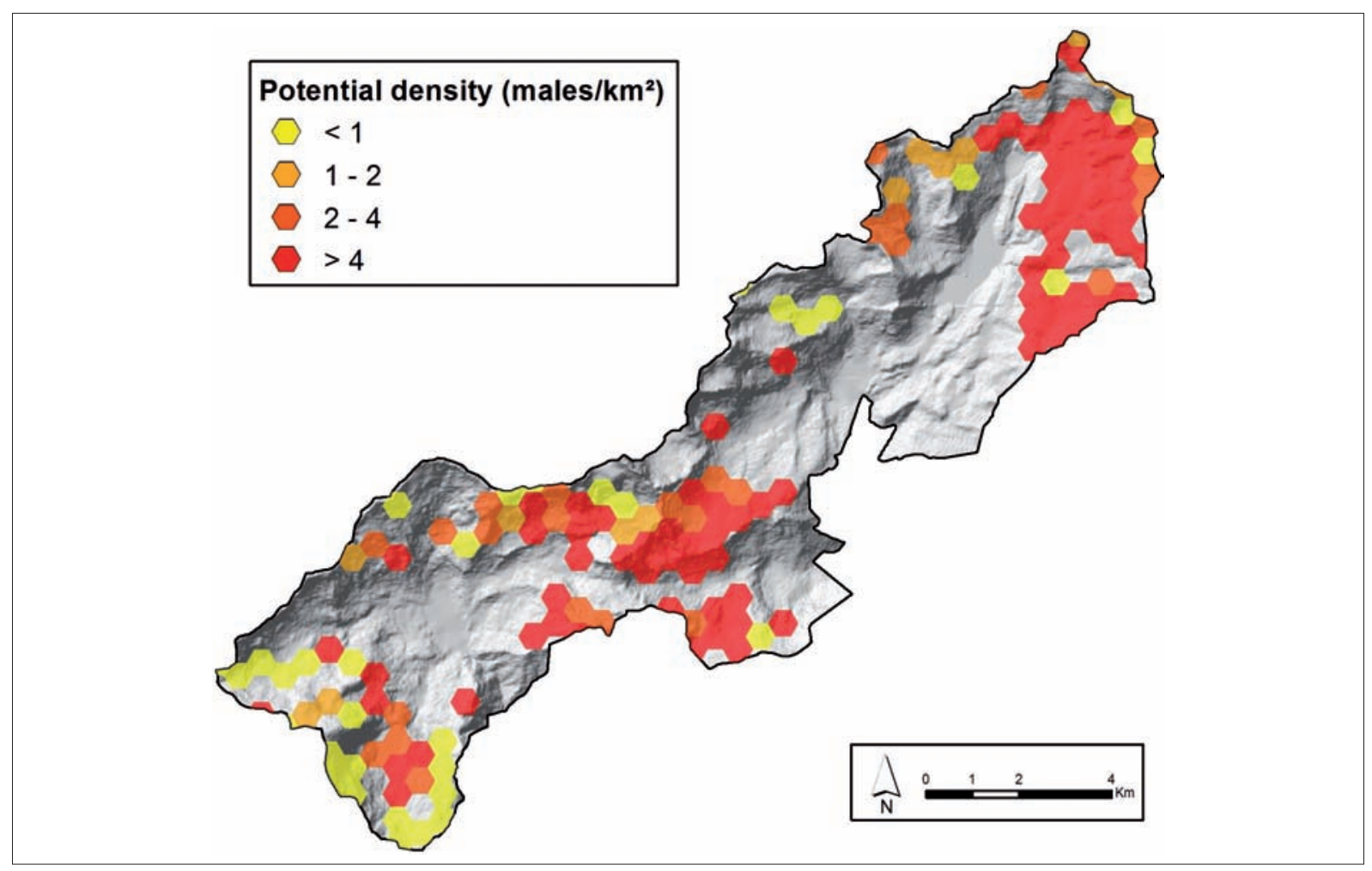

Fig. 4 - Potential density of male rock ptarmigans in the Veglia-Devero Natural Park, Italy. 


\section{DISCUSSION}

Considering the results of the models of Nelli et al. (2013) and those obtained in the present work, it is possible to identify suitability gradients for male rock ptarmigans in the considered study area.

The suitable areas for the presence and abundance of rock ptarmigans represents the whole of the habitat conditions necessary for its conservation and management. The use of habitat suitability models is therefore desirable, because they identify the key factors responsible for the fluctuations of a species and the areas critical to their maintenance and protection.

In the present work, I focused on the effects of habitat variables related to cover types and to orographic features. These two sets of information were good predictors of both the presence and density of male rock ptarmigans. As predictable, my results indicated that plots with higher proportions of alpine grassland had a positive effect on probability of the presence and on density (Favaron et al., 2006; Wilson \& Martin, 2008; Revermann et al., 2012). Unfortunately, no detailed information was available on the effective use of grassland, e.g. the amount of grazing cows during the study period or the spatial location of used pastures. These factors are indeed very important, because they are the origin of many transformations of alpine landscapes and therefore are important for defining the suitability of areas for rock ptarmigans and for other grouses and not-grouses alpine breeding bird in general (Baines, 1996; Magnani, 1998; Calladine et al., 2002; Zeitler, 2003; Angelstam, 2004; Pearce-Higgins et al., 2007; Wegge \& Rolstad, 2011; Cocca et al., 2012).

Another group of variables that I couldn't take into consideration was that related to the anthropogenic impact caused by sport activities. It is well known that both winter and summer activities, such as skiing, snowshoes trails, eliski, hiking, mountain-biking, and paragliding have negative effects on avifauna and in particular on alpine galliforms (Ménoni \& Magnani, 1998; Zeitler, 2001; Patthey et al., 2008; Watson \& Moss, 2004; Arlettaz et al, 2007; Laiolo, 2007) and that these activities should be limited or avoided at least in core areas for species conservation (Storch, 2007), but quantifying these data is difficult to achieve with simple field observations.

Nevertheless, the information contained in the digital maps we used were sufficient to develop models with a good predictive power, although a combined use of different scale models should be encouraged, for example integrating landscape models (obtained by using GISmeasured variables) with species specific ecological data (obtained by field-measured variables) (Brambilla et al., 2009).

At present in the scientific community, there is a fervent debate about which methods and models are the best to define the suitability of a territory and the potential distribution of a species (Liu et al., 2005, 2011; Hernandez et al., 2006). In my work, I decided to use a widely used method in ecology and used 0.5 as threshold for potential presence of the species (Manel et al., 1999a; 1999b; 2001; Luck, 2002; Stockwell \& Peterson, 2002; Woolf et al., 2002).
In Nelli et al. (2013), I showed how grasslands and rocky grasslands were important for defining the suitability of areas for male rock ptarmigans in terms of potential presence. Here I found that the same habitat variables are good predictors in predicting not only the likely presence of the species but also a higher density and thus abundance.

Though north and east facing slopes had a lower predictive importance, they showed a negative effect on density. In Nelli et al. (2013), we didn't use the northness and eastness variables, but we used the integrated metric of solar radiation to evaluate the preference for aspect, and in that case, we obtained a positive effect suggesting a general preference for south-facing slopes. Both these results are in contrast with what was reported by Revermann et al. (2012). The explanations we tried to give in Nelli et al. (2013) were two. The first was due to the sampling method that we used: we sampled males in the first hours of the day when birds display in the first areas exposed to the sun. The second was that the reproductive success of rock ptarmigans is demonstrated to be related to an early date of snowmelt (Novoa et al., 2008; Wilson \& Martin, 2010), so we hypothesized that males during the sample period had already selected those territories that confer higher chick survival. With the results of the present study, I further support these hypotheses.

The majority of studies that evaluate the habitat suitability for an animal species normally use techniques that give the results as the probability of species presences and therefore the potential distribution (Liu et al., 2005; Allouche et al., 2006; Miller, 2014). The potential distribution of a species is important to determine, but in some cases estimating the potential density and abundance and therefore the carrying capacity of a habitat can supply tools for better understanding the species ecology in a particular area. The rock ptarmigan on the Alps is particularly suffering the effects of climate change (Imperio et al., 2013) and to counterbalance it, protecting the parts of more suitable land with more aimed interventions is desirable. Economic resources are limited, especially for nature conservation, therefore the identification of these priority areas is fundamental.

\section{Acknowledgements}

I sincerely thank A. Meriggi for his suggestions and constant support, A. Franzoi, G. Chiatante, A. Mosini, D. Regine and M. Murru for their invaluable help in data collection, R. Bionda, R. Viterbi, S. Grignolio and V. Bosser Peverelli for their technical and logistic support and $\mathrm{M}$. Brambilla for his helpful comments on the first version of the manuscript. This study was conducted within the INTERREG project "I galliformi alpini sulle alpi occidentali come indicatori ambientali: monitoraggio, conservazione e gestione delle specie - ALCOTRA 2007-2013", between Italy and France, under the supervision of Regione Piemonte, Office National de la Chausse et de la Faune Sauvage, Consiglio Nazionale delle Ricerche and Valle d'Aosta Region. 


\section{REFERENCES}

Allouche O., Tsoar A. \& Kadmon R., 2006 - Assessing the accuracy of species distribution models: prevalence, kappa and the true skill statistic (TSS). Journal of Applied Ecology, 43: 1223-1232.

Akaike H., 1973 - Information theory and an extension of the maximum likelihood principle. In: Second International Symposium on Information Theory. B.N. Petrov e F. Csaki (eds). AkademiaiKiado, Budapest: 267-281.

Angelstam P., 2004 - Habitat thresholds and effects of forest landscape change on the distribution and abundance of black grouse and capercaille. Ecological Bulletins, 51: 173-187.

Anderson D.R., Burnham K.P. \& Thompson W.L., 2000 Null hypothesis testing: problems, prevalence, and an alternative. The Journal of Wildlife Management, 64: 912-923.

Anderson D.R., Link W.A., Johnson D.H. \& Burnham K. P., 2001 - Suggestions for presenting the results of data analysis. The Journal of Wildlife Management, 65: 373-378.

Arlettaz R., Patthey P., Baltic M., Leu T., Schaub M., Palme R. \& Jenni-Eiermann S., 2007 - Spreading freeriding snow sports represent a novel serious threat for wildlife. Proceedings of the Royal Society B-Biological Sciences, 274: 1219-1224.

Bailey S.A., Haines-Young R.H. \& Watkins C., $2002-$ Species presence in fragmented landscapes: modeling of species requirements at the national level. Biological Conservation, 108: 307-316.

Baines D., 1996 - Seasonal variation in lek attendance and lekking behavior by male Black Grouse Tetrao tetrix. Ibis, 138: 177-180.

Boyce M.S., Vernier P.R., Nielsen S.E. \& Schmiegelow F.K.A., 2002 - Evaluating resource selection functions. Ecological Modelling, 157: 281-300.

Brambilla M., Casale F., Bergero V., Crovetto M., Falco R., Negri I., Siccardi P. \& Bogliani, G., 2009 - GISmodels work well, but are not enough: habitat preferences of Lanius collurio at multiple levels and conservation implications. Biological Conservation, 142: 2033-2042.

Calladine J., Baines D. \& Warren P., 2002 - Effects of reduced grazing on population density and breeding success of black grouse in northern England. Journal of Applied Ecology, 39: 772-780.

Clementi T., Stadler M., Gerstgrasser L. \& Carmignola G., 2008 - Relazione sulla situazione dei galliformi alpini ai fini della pianificazione del prelievo venatorio. Ufficio caccia e pesca, Provincia autonoma di Bolzano - Alto Adige. [In Italian].

Cocca G., Sturaro E., Gallo L. \& Ramanzin M., 2012 - Is the abandonment of traditional livestock farming systems the main driver of mountain landscape change in Alpine areas? Land Use Policy, 29: 878-886.

De Franceschi P., 1992 - Pernice bianca. In: Fauna d'Italia. Brichetti P., De Franceschi P. \& Baccetti N. (eds). Calderini editore, Bologna, 29: 708-721.

Estrada A. \& Arroyo B. 2012 - Occurrence vs abundance models: differences between species with varying ag- gregation patterns. Biological conservation, 152: 3745.

Favaron M., Scherini G.C., Preatoni D., Tosi G. \& Wauters L.A., 2006 - Spacing behaviour andhabitat use of rock ptarmigan (Lagopus mutus) at low density in the Italian Alps. Journal of Ornithology, 146: 618-628.

Franceschi S., Nelli L., Pisani C., Fattorini L. \& Meriggi A., 2014 - A Monte Carlo appraisal of plot and distance sampling for surveys of black grouse and rock ptarmigan populations in Alpine protected areas. The Journal of Wildlife Management, 78: 359-368.

Gustin M., Brambilla M. \& Celada C., 2009 - Valutazione dello stato di conservazione dell'avifauna italiana. Ministero dell'Ambiente, della Tutela del Territorio e del Mare \& LIPU/BirdLife Italia, Roma. [In Italian].

Hernandez P.A., Graham C.H., Master L.L. \& Albert D.L., 2006 - The effect of sample size and species characteristics on performance of different species distribution modeling methods. Ecography, 29: 773-785.

Imperio S., Bionda R., Viterbi R. \& Provenzale A., 2013 - Climate change and human disturbance can lead to local extinction of Alpine Rock Ptarmigan: new insight from the Western Italian Alps. PLoS ONE, 8: e81598.

Jiménez-Valverde A. opinion: Relationship between local population density and environmental suitability estimated from occurrence data. Frontiers of Biogeography, 3: 59-62.

Laiolo P., 2007 - Monitoring the effects of ski resorts on wildlife: Case studies from Italian Alps. Environment, local society and sustainable tourism, 50: 23-30.

Liu C., Berr, P.M., Dawson, T.P. \& Pearson, R.G., 2005 Selecting thresholds of occurrence in the prediction of species distributions. Ecography, 28: 385-393.

Liu C., White M. \& Newell G., 2011 - Measuring and comparing the accuracy of species distribution models with presence-absence data. Ecography, 34: 232-243.

Luck G.W., 2002 - The habitat requirements of the rufous treecreeper (Climacteris rufa). 2. Validating predictive habitat models. Biological Conservation, 105: 395403.

Magnani Y., 1988 - Selection de l'habitat de reproduction et influence de l'evolution des pratiquessylvo-pastoralessur la population de tetras lyre (Tetrao tetrix) de la reserve des Fretes (Haute-Savoie). Gibier Faune Sauvage, 5: 289-307. [In French].

Manel S.E.P., Dias J.M., Buckton S.T. \& Ormerod S.J., 1999a - Alternative methods for predicting species distributions: an illustration with Himalayan river birds. Journal of Applied Ecology, 36: 734-747.

Manel S., Dias J.M. \& Ormerod S.J., 1999b - Comparing discriminant analysis, neural networks and logistic regression for predicting species distributions: a case study with a Himalayan river bird. Ecological Modelling, 120: 337-347.

Manel S., Williams, H.C. \& Ormerod S.J., 2001 - Evaluating presence-absence models in ecology: the need to account for prevalence. Journal of Applied Ecology, 38: 921-931.

Ménoni E. \& Magnani Y., 1998 - Human disturbance of grouse in France. Grouse News, 15: 4-8. 
Miller J.A., 2014 - Virtual species distribution models: using simulated data to evaluate aspects of model performance. Progress in Physical Geography, 38: 117128.

Nelli L., Meriggi A. \& Franzoi A., 2013 - Habitat selection by breeding rock ptarmigan Lagopus muta helvetica males in the Western Italian Alps. Wildlife biology, 19: 382-389.

Nielsen S.E., Johnson C.J., Heard D.C. \& Boyce H.D., 2008 - Can models of presence-absence be used to scale abundance? Two case studies considering extremes in life history. Ecography, 28: 197-208.

Nopp-Mayr U. \& Zohmann M., 2008 - Spring densities and calling activities of Rock Ptarmigan (Lagopus muta helvetica) in the Austrian Alps. Journal of Ornithology, 149: 135-139.

Novoa C., Besnard A., Brenot J.F. \& Ellison L., 2008 Effect of weather on the reproductive rate of Rock Ptarmigan Lagopus muta in the eastern Pyrenees. Ibis, 150: 270-278.

Patthey P., Wirthner S., Signorell N. \& Arlettaz R., 2008 Impact of outdoor winter sports on theabundance of a key indicator species of alpine ecosystems. Journal of Applied Ecology, 45: 1704-1711.

Pearce-Higgins J.W., Grant M.C., Robinson M.C. \& Haysom S.L., 2007 - The role of forest maturation in causing the decline of Black Grouse Tetrao tetrix. Ibis, 149: 143-155.

Peronace, V., J. G. Cecere, M. Gustin \& Rondinini C., 2012 - The 2011 Red List of Italian breeding birds. Avocetta, 36: 11-58. [In Italian].

Pitelka L.F. \& Pitelka F.A., 1993 - Environmental decision making: multidimensional dilemmas. Ecological Applications, 3: 566-568.

Revermann R., Schmid H., Zbinden N., Spaar R. \& Schörder B., 2012 - Habitat at the mountain tops: how long can Rock Ptarmigan Lagopus muta helvetica survive rapid climate change in the Swiss Alps? A multi-scale approach. Journal of Ornithology, 153: 891-905.

Rotelli L., 2006 - Limiting factors and causes of decline in alpine galliformes in Italy: implications for conservation and management. In: Proceedings of meeting on Alpine Grouses, conservation and management experiences across Europe. Regione Piemonte, Assessorato Agricoltura, Tutela della fauna e della flora, 28 November 2006, Turin, Italy: 130-147.

Stockwell D.R.B. \& Peterson A.T., 2002 - Effects of sample size on accuracy of species distribution models. Ecological Modelling, 148: 1-13.

Spagnesi M. \& Serra L., 2004 - Uccelli d'Italia. Quaderni di Conservazione della Natura 21. Ministero dell'Ambiente, Istituto Nazionale della Fauna.

Storch I., 2000 - Conservation status and threats to grouse worldwide: an overview. Wildlife Biology, 6: 213-222.

Storch I., 2007 - Grouse: Status Survey and Conservation Action Plan 2006-2010. Gland, Switzerland and Fordingbridge, UK: World Pheasant Association.

Watson A. \& Moss R., 2004 - Impact of ski-development on ptarmigan (Lagopus mutus) at Cairn Gorm, Scotland. Biological Conservation, 116: 267-275.
Wegge P. \& Rolstad J., 2011 - Clearcutting forestry and Eurasian boreal forest grouse Long-term monitoring of sympatric capercaillie Tetrao urogallus and black grouse Tetrao tetrix reveal unexpected effects on their population performances. Forest Ecology and Management, 261: 1520-1529.

Wilson S. \& Martin K., 2008 - Breeding habiat selection of sympatric White-tailed, Rock and Willow Ptarmigan in the southern Yukon Territory, Canada. Journal of Ornithology, 149: 629-637.

Wilson S. \& Martin K., 2010 - Variable reproductive effort for two ptarmigan species in response to spring weather in a northern alpine ecosystem. Journal of Avian Biology, 41: 319-326.

Woolf A., Nielsen C.K., Weber T. \& Gibbs-Kieninger T.J., 2002 - Statewide modeling of bobcat, Lynx rufus, habitat in Illinois, USA. Biological Conservation, 104: 191-198.

Wöss M. \& Zohmann M. 2004 - Bestandsaufnahme beim Alpenschneehuhn Lagopus mutus in einem Teilgebiet der Nationalparkregion Nockberge, Oesterreich. Ornithologische Beobachter, 101: 209-218. [In German with English summary: Estimation of population density and distribution of Ptarmigan Lagopus mutus in the Nockberge National Park, Austrian Alps].

Zar J.H., 1999 - Biostatistical Analysis. Prentice Hall, New Jersey.

Zeitler A., 2001 - Human disturbance, behavior and spatial distribution of Black Grouse in skiingareas in the Bavarian Alps. Cahiers d'Ethologie, 20: 1-22.

Zeitler A., 2003 - Maintaining Black Grouse wintering habitats by alpine pasture management plans. Sylvia, 39: 97-102.

Zohmann M. \& Wöss M., 2008 - Spring density and summer habitat use of alpine rock ptarmigan Lagopus muta Helvetica in the southeastern Alps. European Journal of Wildlife Research, 54: 379-383.

Zuur A.F., Ieno E.N. \& Elphick C.S., 2010 - A protocol for data exploration to avoid common statistical problems. Methods in Ecology \& Evolution, 1: 3-14. 